\title{
Chinese rose (Rosa chinensis) cultivation in Bohai Bay, China, using an improved drip irrigation method to reclaim heavy coastal saline soils
}

\author{
Xiulong Chen ${ }^{\mathrm{a}, \mathrm{b}}$, Yaohu Kang ${ }^{\mathrm{a}, *}$, Shuqin Wan ${ }^{\mathrm{a}}$, Linlin Chu ${ }^{\mathrm{a}}$, Xiaobin $\mathrm{Li}^{\mathrm{a}} \mathrm{b}$ \\ ${ }^{a}$ Key Laboratory of Water Cycle and Related Land Surface Processes, Institute of Geographic Sciences and Natural Resources Research, Chinese Academy of \\ Sciences, Beijing 100101, China \\ ${ }^{\mathrm{b}}$ Graduate University of Chinese Academy of Sciences, Beijing 100049, China
}

\section{A R T I C L E I N F O}

\section{Article history:}

Received 24 July 2014

Received in revised form 21 April 2015

Accepted 24 April 2015

Available online 14 May 2015

\section{Keywords:}

Soil matric potential

Reclamation

Chinese rose

Salt-sensitive plant

\begin{abstract}
A B S T R A C T
This study investigated whether an improved drip irrigation method for reclaiming heavy coastal saline silt-soils could improve the growth of salt-sensitive plants threatened by soils with high salt contents and poor soil structures in Bohai Bay, China. Chinese rose (Rosa chinensis), an ornamental salt-sensitive plant, was chosen as the experiment material. The improved method used a non-saline root environment during the early stages of salt-leaching, a gravel-sand layer settled below the saline soil but above the water table and optimal soil moisture conditions. To determine the optimal soil moisture conditions, five soil matric potentials (SMPs) at $20 \mathrm{~cm}$ depth at $-5,-10,-15,-20$ and $-25 \mathrm{kPa}$ were studied. The results indicated that the mean soil electrical conductivity of the saturated paste extracts (ECe) and the sodium adsorption ratio (SAR) significantly declined in all five treatments. After three growing seasons, the highest desalinization ratios and SAR reductions reached $89 \%$ and $73 \%$, respectively, compared with their initial values and these occurred in the roots of the seedlings exposed to the $-5 \mathrm{kPa}$ treatment. The mean ECe and SAR values increased linearly as the SMP declined. The plant survival ratio was not affected by the SMP treatment in the first growing season, due to the non-saline root zone, but decreased significantly as the SMP threshold fell in the spring of the second year, and then remained stable in the following season. The highest survival ratio reached $97 \%$ for the $-5 \mathrm{kPa}$ SMP treatment after three growing seasons. Stem diameter and plant height increased during three growing seasons and the largest increases occurred when the SMP was $-5 \mathrm{kPa}$ in first year, $-10 \mathrm{kPa}$ in second year and $-20 \mathrm{kPa}$ in third year. The largest crown diameters were recorded in the $-5 \mathrm{kPa}$ treatment plots in second year and $-20 \mathrm{kPa}$ in third year. After three years of reclamation, our results showed that this improved method, which utilized a non-saline root environment during the early stages of salt-leaching, a gravel-sand layer below the saline soil and controlled the SMP threshold of $-5 \mathrm{kPa}$ in the first year, $-10 \mathrm{kPa}$ in second year and $-20 \mathrm{kPa}$ in third year, can be used to reclaim coastal urban saline land for vegetation rehabilitation around Bohai Bay, China.
\end{abstract}

(c) 2015 Elsevier B.V. All rights reserved.

\section{Introduction}

Over $70 \%$ of the larger Chinese cities are located along $1.8 \times 10^{4} \mathrm{~km}$ of coastline next to the Pacific Ocean and coastal development in China plays a leading role in the national economy, accounting for $55 \%$ of its gross domestic productivity (GDP; Cao and Wong, 2007). Furthermore, there is a $1.0 \times 10^{4} \mathrm{~km}^{2}$ area of coastal saline land along the $0.6 \times 10^{4} \mathrm{~km}$ coastline that extends from Jiangsu Province to Liaoning Province in north China (Yu and Chen, 1999; Yue et al., 2010). However, the cities located on this

\footnotetext{
* Corresponding author. Tel.: +86 106485 6516; fax: +86106486516

E-mail address: kangyh@igsnrr.ac.cn (Y. Kang).
}

land have difficulties establishing vegetation due to the soil being saline.

The coastal saline soil has a high salinity with mean electrical conductivity of saturated paste extracts (ECe) between $15 \mathrm{dS} \mathrm{m}^{-1}$ and $65 \mathrm{dS} \mathrm{m}^{-1}$ and the dominant ions are sodium ( $\mathrm{Na}$ ) and chlorine (Cl), which comprise more than $80 \%$ of total cations and more than $75 \%$ of total anions, respectively. This is similar to the ion composition of sea water (Wang et al., 1993).The shallow groundwater is 86 to $112 \mathrm{~cm}$ below ground and its electrical conductivity is between 4.9 and $20.5 \mathrm{dS} \mathrm{m}^{-1}$ (He et al., 2003). In particular, these coastal areas contain a heavy, highly saline silt-soil that has a bulk density of $1.7 \mathrm{~g} \mathrm{~cm}^{-3}$. This characteristic results in poorly aerated soils with low permeability. Therefore, coastal saline soils severely limit urban vegetation rehabilitation. 
The traditional methods used in saline soil reclamation are chemical treatment with gypsum (Hoogerwerf et al., 1992; Schuman et al., 1994; Musslewhite et al., 2009), physical treatments, such as combining surface irrigation and water drainage technologies, e.g. drainage ditches and subsurface pipe drainage (Manjunatha et al., 2004; Ritzema and Schultz, 2011), and planting halophytes (Zedler et al., 2003; Ravindran et al., 2007). At present, the most popular saline soil reclamation method in our research area is replacing coastal saline soil with non-saline soil (Sun et al., 2012). However, the method is very expensive and is not sustainable due to the thin non-saline soil layer and shallow saline groundwater.

Drip irrigation can maintain high soil moisture, low soil salinity and well-aerated condition in the root zone, is considered to be the most efficient irrigation method for reclaiming salt-affected soils (Hanson, 1995; Hanson and May, 2003; Hanson et al., 2009). In China, using soil matric potential (SMP) at a depth of $0.2 \mathrm{~m}$ measured by tensiometers to control the timing and amount of irrigation during reclamation of salt-affected soils under cropped conditions has been successful carried out under a wide range of conditions. In the Ningxia Plain, China (Kang et al., 2008; Jiao et al., 2008; Tan and Kang, 2009; Wan et al., 2013), irrigation at a SMP greater than $-10 \mathrm{kPa}$, a highly saline soil $\left(\mathrm{ECe}>20 \mathrm{dS} \mathrm{m}^{-1}\right)$ was shifted to a moderately saline soil $\left(7 \mathrm{dS} \mathrm{m}^{-1}<\mathrm{ECe}<9 \mathrm{dS} \mathrm{m}^{-1}\right)$ in three cropping seasons. In Xinjiang, northwest China, irrigation of cotton at $-5 \mathrm{kPa}$ of a saline wasteland for three years (Wang et al., 2011 ) resulted in seed-cotton yields reaching $84 \%$ of non-saline soil after three years. Liu et al. (2011) reported similar success for SMP controlled irrigation when SMP ranged from $-5 \mathrm{kPa}$ to $-10 \mathrm{kPa}$ for the restoration of saline-sodic grassland in the Songnen Plain, northeast China. Zhang et al. (2013) reported that the low infiltration rate at the surface of saline-sodic soils could be solved by digging sand-filled holes beneath the drip emitter, and irrigation by controlling SMPs between $-15 \mathrm{kPa}$ and $-20 \mathrm{kPa}$ resulted in high plant survival (>80\%) and fruit yields (around $900 \mathrm{~kg} \mathrm{ha}^{-1}$ ), which were close to the yields achieved by the local farmlands.

Sun et al. (2013) reclaimed coastal saline soil that had the salinity (ECe) of $10.6-25 \mathrm{dS} \mathrm{m}^{-1}$ and a bulk density of $1.55 \mathrm{~g} \mathrm{~cm}^{3}$, by drip irrigation with controlling the SMP to $-5 \mathrm{kPa}$. They found that embedding a $20 \mathrm{~cm}$ thick gravel-sand layer at a depth of $60-80 \mathrm{~cm}$, but above the shallow saline groundwater, significantly reduced the soil ECe to $2.2 \mathrm{dS} \mathrm{m}^{-1}$, and the survival ratios of several of the relatively salt tolerant ornamental plants were significantly high. But they also reported that the survival ratios of salt-sensitive plants (2-4 dS m ${ }^{-1}$; Maas, 1986), such as hibiscus (Hibiscus syrlacus), red leaf cherry plum (Prunus cerasifera Ehrh) and Chinese rose (Rosa chinensis), were significantly affected by all the SMP threshold treatments, and the landscape effect was not good. They indicated that the results may be due to the effects of soil salinity on plant growth during the early stages of salt leaching.

Previous studies have provided many useful methods for the urban revegetation of heavy, highly saline coastal silt-soils. However to achieve good landscape effects, many ornamental salt-sensitive and moderately salt-sensitive species are used in vegetation rehabilitation compared with the salt tolerant or moderately salt tolerant species used in agricultural production. Besides, most green plants are perennial, the drought and salinization in the next spring will harm the survival and growth of these plants. Therefore, based on the previous studies and the regimes used in Sun's studies (Sun et al., 2012, 2013), the aim of this study was to find an improved method (a nonsaline root environment during the early stages of salt-leaching, a gravel-sand layer below the saline soil and optimal soil moisture conditions) to achieve high survival ratio and good growth of saltsensitive plant for reclaiming the coastal saline land around Bohai Bay.
The objectives of this study were as follows: (1) to measure the effects of different soil moisture conditions (SMP threshold treatments) on the salt distribution in the soil profile and growth characteristics of rose, a salt-sensitive plant; and (2) to propose an improved drip irrigation method of vegetation rehabilitation under coastal saline conditions in the urban areas of North China.

\section{Materials and methods}

\subsection{Experimental site}

Field experiments were conducted between 2012 and 2014 on a coastal saline wasteland in Tangshan Bay Eco-city $\left(39^{\circ} 12^{\prime} 19^{\prime \prime} \mathrm{N}\right.$, $118^{\circ} 31^{\prime} 47^{\prime \prime} \mathrm{E}$ ), which is located to the southeast of Tangshan city and northeast of the Bohai Bay, China. The study area has a temperate semi-humid monsoon climate with a mean annual precipitation of $607 \mathrm{~mm}$. Most rainfall falls between June and September. Seasonal droughts are frequent in spring and autumn. The average evaporation in this region is $1677 \mathrm{~mm}$ and it is cold, dry and windy in winter and spring.

The soil is mainly a heavy, highly saline silt-soil. The average soil texture in the $0-120 \mathrm{~cm}$ soil layer is silt, where $0.8 \%$ of the particles are less than $0.002 \mathrm{~mm}$ in size, $80 \%$ of the particles are between 0.002 and $0.05 \mathrm{~mm}$ and $19 \%$ of the particles are larger than $0.05 \mathrm{~mm}$. The electrical conductivities, $\mathrm{pHs}$ and sodium adsorption ratios of the saturated soil extracts (ECe, pH and SAR) taken from the initial soil profile ranged from 23.5 to $34.5 \mathrm{dS} \mathrm{m}^{-1}, 7.5$ to 7.7 and 54.8 to $66.8\left(\mathrm{mmol} \mathrm{L}^{-1}\right)^{0.5}$, respectively, and the soil bulk density was between 1.66 and $1.75 \mathrm{~g} \mathrm{~cm}^{-3}$. The groundwater table is $1.5-1.8 \mathrm{~m}$ below ground surface. Detailed information on the initial soil profile is shown in Table 1.

\subsection{Plant management and experimental design}

\subsubsection{Soil preparation and plant management}

The soil in the experimental area $(16 \mathrm{~m} \times 10 \mathrm{~m})$ was first deepplowed to a depth of $120 \mathrm{~cm}$ using an excavator on 25 May 2012. Between the 26 and 27 May 2012, the soil was removed to a depth of $120 \mathrm{~cm}$ and a $15 \mathrm{~cm}$ thick gravel layer was placed at the bottom. This was then covered with a $5 \mathrm{~cm}$ thick layer of sand with native soil placed above the sand (Fig. 2), which was similar to the method followed by Sun et al. (2013). The aim was to prevent upper water movement from a shallow, very saline groundwater table. Compared with the $0.6-0.8 \mathrm{~m}$ soil thickness above the gravel-sand layer of Sun et al. (2013), the soil thickness of this experiment was $1.2 \mathrm{~m}$ so as to provide enough soil space to store more moisture and nutrients for plant growth, especially when the plants grow larger. Two $110 \mathrm{~cm}$ diameter polyvinylchloride pipes were used to connect the gravel-sand layer with a large, natural pond. The water depth of the pond was about $1.8 \mathrm{~m}$ lower than the gravel-sand layer. The slope was kept at $1.5 \mathrm{~m}$ per $100 \mathrm{~m}$ to ensure that excess water in the soil profile flowed out of the gravel-sand layer and into the pond. When soil preparation had finished, the surface of experimental soil was about $20 \mathrm{~cm}$ higher than the surrounding area. A small drainage ditch was then dug around the experimental area to provide drainage for runoff. The experimental area was divided into 15 experimental treatment plots. The mean soil bulk density was $1.72 \mathrm{~g} \mathrm{~cm}^{-3}$ before the soil was deep-plowed, but decreased to $1.50 \mathrm{~g} \mathrm{~cm}^{-3}$ after deepplowing.

Chinese rose ( $R$. chinensis), a popular perennial plant for urban vegetation construction, was chosen as the experimental material. Roses are considered to be salt-sensitive plants with salt threshold values of $2-3 \mathrm{dS} \mathrm{m}^{-1}$ (Maas, 1986). The roses were transplanted on 1 June 2012 . They were transplanted into five rows at $0.6 \mathrm{~m}$ 
Table 1

Basic properties, electrical conductivity of saturated paste extracts (ECe), SAR and pH value of initial soil profile.

\begin{tabular}{|c|c|c|c|c|c|c|c|c|}
\hline \multirow[t]{2}{*}{ Soil layers $(\mathrm{cm})$} & \multicolumn{3}{|c|}{ Soil mechanical composition (\%) } & \multirow[t]{2}{*}{ Soil texture } & \multirow{2}{*}{$\begin{array}{l}\text { Soil bulk density } \\
\left(\mathrm{g} \mathrm{cm}^{-3}\right)\end{array}$} & \multirow[t]{2}{*}{ ECe $\left(\mathrm{dS} \mathrm{m}^{-1}\right)$} & \multirow{2}{*}{$\begin{array}{l}\text { SAR } \\
\left(\mathrm{mmol} \mathrm{L}^{-1}\right)^{0.5}\end{array}$} & \multirow[t]{2}{*}{$\mathrm{pH}$} \\
\hline & $<0.002 \mathrm{~mm}$ & $0.002-0.05 \mathrm{~mm}$ & $0.05-2.0 \mathrm{~mm}$ & & & & & \\
\hline $0-10$ & 0.8 & 80.0 & 19.2 & Silt & 1.66 & 34.5 & 66.8 & 7.51 \\
\hline $10-20$ & 0.6 & 80.0 & 19.4 & Silt & 1.75 & 31.4 & 63.7 & 7.54 \\
\hline $20-30$ & 0.9 & 77.3 & 21.8 & Silt & 1.75 & 25.4 & 57.1 & 7.63 \\
\hline $30-40$ & 0.7 & 80.7 & 18.6 & Silt & 1.73 & 25.0 & 56.6 & 7.63 \\
\hline $40-60$ & 0.4 & 81.9 & 17.7 & Silt & 1.72 & 23.5 & 54.8 & 7.66 \\
\hline $60-80$ & 0.6 & 80.6 & 18.8 & Silt & 1.73 & 24.1 & 55.6 & 7.65 \\
\hline $80-100$ & 1.1 & 78.9 & 20.0 & Silt & 1.71 & 24.0 & 55.5 & 7.65 \\
\hline $100-120$ & 1.0 & 78.8 & 20.2 & Silt & 1.71 & 24.8 & 56.4 & 7.64 \\
\hline Average & 0.8 & 80.0 & 19.2 & Silt & 1.72 & 25.7 & 57.4 & 7.62 \\
\hline
\end{tabular}

intervals between rows and at $0.5 \mathrm{~m}$ intervals within rows. There were 30 plants in each plot. Sun et al. (2013) indicated that the survival ratios of salt-sensitive plants may be affected by soil salinity during the early salt-leaching period. To prevent this happening, each plant was transplanted into a hole that was bigger than the rose root ball and then non-saline sandy soil was placed in the space between the root ball and the saline soil (Fig. 1A). The aim was to form a non-saline root environment for rose root growth during the early stages of salt-leaching and to maintain an unlimited soil hydraulic conductivity in the root zone, and this was similar to the method used by Zhang et al. (2013). The experiment lasted from June 2012 to May 2014. The plant height (from the soil surface to the top of the highest branch), stem diameters (measured just above the soil surface where there were no branches), average crown diameters and survival ratio of roses (actual plants in each plot divided by the roses established on 1 June 2012) were measured throughout the growing seasons. Before roses were established, an automatic weather station was installed in the experimental area on 23 May 2012.

\subsubsection{Experiment design}

Five SMP treatments were set up to determine the optimal soil moisture conditions for rose growth. The SMP at $20 \mathrm{~cm}$ depth below each emitter was maintained at $-5 \mathrm{kPa}(\mathrm{S} 1),-10 \mathrm{kPa}(\mathrm{S} 2)$, $-15 \mathrm{kPa}$ (S3), $-20 \mathrm{kPa}$ (S4) or $-25 \mathrm{kPa}$ (S5). Each SMP treatment was replicated three times in a completely randomized block design and each plot was $3 \mathrm{~m} \times 3 \mathrm{~m}$ in size. The irrigation water was taken from a $300 \mathrm{~m}$ depth motor-pumped well with electrical conductivity (EC) of $0.75 \mathrm{dS} \mathrm{m}^{-1}, \mathrm{pH}$ of 8.34 and sodium adsorption ratio (SAR) of $4.63\left(\mathrm{mmol} \mathrm{L}^{-1}\right)^{0.5}$. The SMP was measured using a
(A)

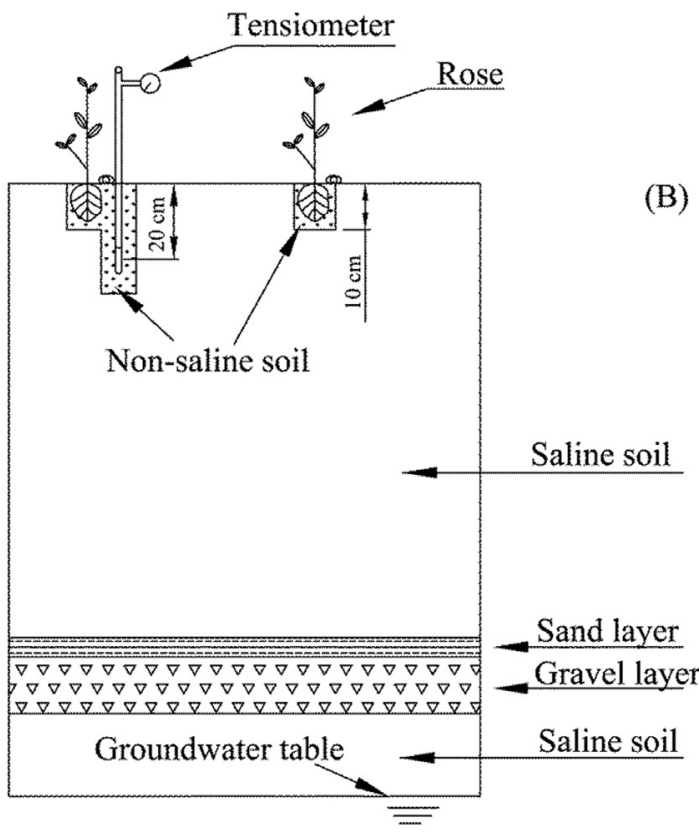

(C)

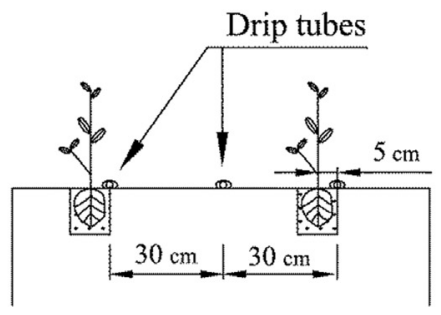

(B)

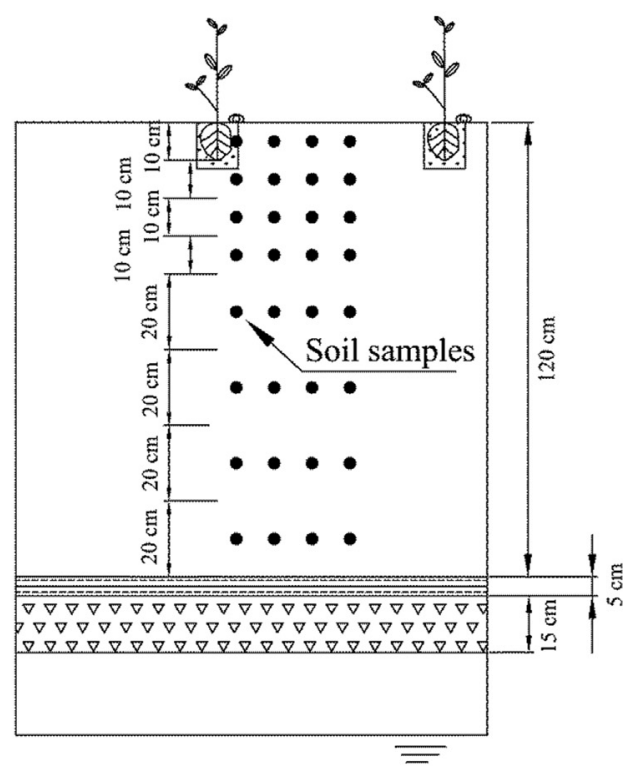

(D)

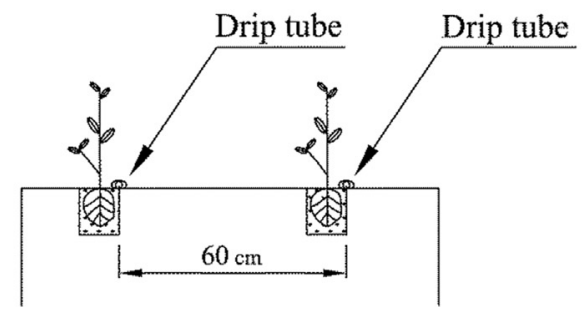

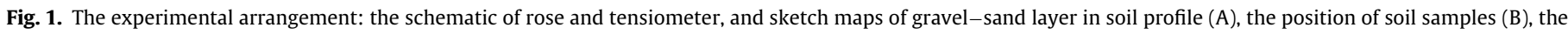
layout of drip tubes in the first irrigation stage (C), the layout of drip tubes after the first irrigation stage (D). 
vacuum gauge tensiometer that was located immediately under the emitter and buried to a depth of $20 \mathrm{~cm}$ (Fig. 1A).

\subsubsection{Irrigation and fertilization}

The irrigation period during the experiment was divided into three stages. In the first stage, a gravity drip irrigation system was used to supply irrigation water for all experimental area. The water head was located $0.5 \mathrm{~m}$ above the soil surface and was controlled by a bucket in which a float had been installed. The emitter discharge rate was $0.3 \mathrm{Lh}^{-1}$. Two drip tubes were placed at $30 \mathrm{~cm}$ distance and the space between two closed emitters was also $30 \mathrm{~cm}$. One of two tubes was placed at $5 \mathrm{~cm}$ distance between the tubes and rose root (Fig. 1C).

During the first stage, irrigation was stopped as soon as surface water appeared in the depressions on the ground. Irrigation was only started again when the surface water disappeared. If rainfall occurred during the irrigation, irrigation was continued to prevent the salt at the perimeter of wetted soil volume moving back towards the emitter or the rose root zone. When the EC (measured with an in situ conductivity meter) at $0-20 \mathrm{~cm}$ was around $3 \mathrm{dS} \mathrm{m}^{-1}$, the first irrigation stage was terminated. The first irrigation stage lasted from 1 to 5 June 2012. At this stage, most of the salts accumulated on the soil surface were leached so as to protect the non-saline root environment.

During the second irrigation stage, the emitter discharge rate was still kept at $0.3 \mathrm{~L} \mathrm{~h}^{-1}$ but the drip tubes were reduced to one per plant row (Fig. 1D). A tensiometer was installed at $0.2 \mathrm{~m}$ depth in each treatment plot to trigger irrigation and the reading was made twice daily (8:00 and 17:00) to determine the appropriate water application time. If the soil matric potential (SMP) fell below $-5 \mathrm{kPa}$, all the treatments were uniformly irrigated with $6 \mathrm{~mm}$ of water, until all the rose plants had successfully established in the experimental soil. The first and second irrigation stages were collectively named the reclamation stage.

The third irrigation stage started as soon as all the roses were successfully established. In the third stage, the treatments were connected to individual gravity drip-irrigation systems, which irrigated the plants from a tank containing $200 \mathrm{~L}$ irrigation water (installed $1.2 \mathrm{~m}$ above the ground). The emitter discharge rate was changed to about $0.48 \mathrm{~L} \mathrm{~h}^{-1}$ and the drip tubes were one per plant row (Fig. 1D). All the SMP threshold treatments were irrigated according to their target SMP value and each treatment was irrigated with $6 \mathrm{~mm}$ of water per irrigation. In the early spring (4-8 April, spring irrigation) and later winter (25-30 November, winter irrigation), the water irrigation depth for all treatments was increased from the normal depth of $6 \mathrm{~mm}$ to $24 \mathrm{~mm}$. Every experimental plot was protected by non-woven fabric covers during the first winter and spring (2012-2013) to resist the cold and wind. The covers were removed on 3 March 2013 because the weather began to warm up. No plant protection was provided in the second winter and spring (2013-2014).

Urea (44\% nitrogen) and potassium dihydrogen phosphate (54\% phosphate and $32 \%$ potassium) were applied by adding them to the irrigation water. Over the entire experimental period, the total amount of urea and potassium dihydrogen phosphate applied was about 73 and $59 \mathrm{~kg} \mathrm{ha}^{-1}$ per year.

\subsection{Soil sample observation and analysis}

Soil samples were taken from each plot with an auger $3.0 \mathrm{~cm}$ diameter and $10 \mathrm{~cm}$ height) before the roses had established (24 June 2012), after the reclamation stage (1 July 2012), at the end of 2012 (30 October 2012), at the beginning of 2013 (24 March 2013), at the end of 2013 (1 November 2013), at the end of 2014 (20 November 2014). The samples were taken 0,10, 20 and $30 \mathrm{~cm}$ away from the emitters and the sampling depths were $0-10,10-20$,
20-30, 30-40, 40-60, 60-80, 80-100 and 100-120 cm (Fig. 1B). All the soil samples were air-dried and passed through a $1 \mathrm{~mm}$ sieve. Soluble salt estimates and the sodium adsorption ratios (SAR) were calculated from saturated soil extracts. In this study, ECe is the electrical conductivity of the saturated soil extract. ECe was determined using a conductivity meter (DDS-11, REX, Shanghai), $\mathrm{Ca}^{2+}$ and $\mathrm{Mg}^{2+}$ were measured using the EDTA titration method and $\mathrm{Na}^{+}$by flame photometry as described by Bao (2000). The SAR of the saturated paste extract was calculated as follows:

$\mathrm{SAR}=\frac{\left[\mathrm{Na}^{+}\right]}{\left(\left[\mathrm{Ca}^{2+}\right]+\left[\mathrm{Mg}^{2+}\right]\right)^{0.5}}$.

where the concentration of each cation is in $\mathrm{mmol} \mathrm{L}^{-1}$.

Under high-frequency drip irrigation, most roots of plants were concentrated mainly within $40 \mathrm{~cm}$ depth due to the restricted volume of wetted soil (Phene et al., 1991; Kang and Wan, 2005; Wang et al., 2011). In this experiment, the mean ECe values for the root zone $(0-40 \mathrm{~cm})$ and the whole soil profile $(0-120 \mathrm{~cm})$ were integrated to account for both spatial and temporal variations. The mean ECe (or SAR) values on date $t(\mathrm{ECe}(t))$ ( or SAR $(t)$ ) were calculated from ECe $(j, k)(\operatorname{or} \operatorname{SAR}(j, k)$ and $S(j, k)(j=0,10,20,30 ; k=0-10$, $10-20,20-30,30-40$ for the root zone, and $k=0-10,10-20,20-30$, $30-40,40-60,60-80,80-100,100-120$ for the whole soil profile).

The mean value for ECe in the soil profile on date $t$ was calculated as follows:

$\overline{\operatorname{ECe}(t)} \quad[$ or $\overline{\operatorname{SAR}(t)}]=\frac{\sum_{j, k}^{n, m} \operatorname{ECe}(t, j, k)[\operatorname{orSAR}(t, j, k)] \times S(j, k)}{\sum_{j, k}^{n, m} S(j, k)}$

where $t$ represents the time at which soil samples were obtained; $j$ the four $(n)$ distances from the emitter where soil samples were attained for both the root zone and the whole soil profile; $k$ the four depths of soil samples for the root zone and the eight depths of soil samples for the whole soil profile; $S(j, k)$ the depth interval of the soil sample.

The desalinization ratio was calculated as follows:

$\operatorname{ECe}(d)=\frac{\overline{\operatorname{ECe}(i)}-\overline{\operatorname{ECe}(i+n)}}{\overline{\operatorname{ECe}(i)}} \%$

where $\operatorname{ECe}(i)$ and $\operatorname{ECe}(i+n)(n=1,2,3$ and 4) refer to the spatial weighted mean value of the soil profile at the first and $n$th salt leaching stages, respectively.

\subsection{Statistical analysis}

Analysis of variance (ANOVA) was conducted to evaluate the effects of the factors on stem diameter, plant height and survival ratio. Two factors, determination time ( $n=2$, i.e. 2012, 2013), and SMP $(n=5$, i.e. $-5,-10,-15,-20$ and $-25 \mathrm{kPa})$, were included. Duncan's multiple range tests were used to compare and rank the treatment means. Differences were significant at $p \leq 0.05$. The average crown diameter was only measured at the end of the second growing season, so it was analyzed by single-factor analysis of variance, and differences were significant at $p \leq 0.05$. General linear model (GLM) method of ANOVA was conducted to evaluate the main effects of factors on ECe and SAR data in root zone and whole soil profile. Two factors, SMP $(n=5$, i.e. $-5,-10,-15,-20$ and $-25 \mathrm{kPa})$, Sampling time $(n=4$, i.e. at the end of 2012 , at the beginning of 2013, at the end of 2013, and at the beginning of 2014) were included. The ECe values were different in five treatment plots after the reclamation stage, so covariance analysis with the ECe value as covariates was carried out. 


\section{Results and discussion}

\subsection{Precipitation}

The rainfall data during the three growth periods (2012, 2013 and 2014) are shown in Fig. 2. The total rainfall was 693.8, 425.3 and $450.0 \mathrm{~mm}$ in 2012 (from 23 May to 27 December), 2013 and 2014, respectively. They contained 21, 12 and 13 effective rainfall ( $>10 \mathrm{~mm} \mathrm{~d}^{-1}$ ) events, respectively. Around $83 \%, 88 \%$ and $76 \%$ of total rainfall in 2012, 2013 and 2014, respectively, occurred between June and September. There were three torrential rain events (rainfall intensity $>50 \mathrm{mmd}^{-1}$ ) on 3 June (about $51.2 \mathrm{~mm}$ ), 3 August (about $74.8 \mathrm{~mm}$ ) and 7 September in 2012; one event on 8 August (about $92.8 \mathrm{~mm}$ ) in 2013 and, two events on 18 August (about $58.8 \mathrm{~mm}$ ) and 2 September (about $75 \mathrm{~mm}$ ) in 2014. There were also four, three and two heavy rainfall events $\left(50>\right.$ rainfall intensity $>25 \mathrm{~mm} \mathrm{~d}^{-1}$ ), and fourteen, eight and nine drizzle events $\left(25>\right.$ rainfall intensity $\left.>10 \mathrm{mmd}^{-1}\right)$ in 2012 , 2013 and 2014, respectively. In the reclamation stage, rainfall of $167.6 \mathrm{~mm}$ occurred (65.6 and $102 \mathrm{~mm}$ occurred in the first and second irrigation stage, respectively). During treatment, the rainfall was $526 \mathrm{~mm}$ for the first year, and 425.3 and $450 \mathrm{~mm}$ for the second and three year, respectively (Table 2).

The rainfall before 23 May 2012 was not determined because the experimental plots had not been prepared, so the actual rainfall recorded in 2012 was $86 \mathrm{~mm}$ more than the overall mean annual precipitation for the area. However, the actual rainfall recorded in 2013 and 2014 was $182 \mathrm{~mm}$ and $157 \mathrm{~mm}$ below the overall mean annual rainfall for the area, so 2012 represented a wet year and both 2013 and 2014 represented dry years, respectively.

\subsection{Irrigation and soil matric potential}

\subsubsection{Irrigation}

During the reclamation stage, total irrigation water of $130 \mathrm{~mm}$ was applied to each treatment (Table 2). The details were: irrigation water applied was about $20 \mathrm{~mm}$ on 1 June, and then about $30 \mathrm{~mm}$ on both 2 and 3 June due to the rain that fell on those two days (rainfall of 14.4 and $51.2 \mathrm{~mm}$ occurred on 2 and 3 June, respectively), and a further $10 \mathrm{~mm}$ was applied on both 4 and 5 June, during the first irrigation stage. In the second irrigation stage, the target SMP was controlled above $-5 \mathrm{kPa}$, and five irrigations supplied $30 \mathrm{~mm}$ water for all experimental area.

During the third irrigation stage, irrigation occurred only when the soil matric potential (SMP) reached the target values for S1, S2, S3, S4 and S5. The number of irrigations and irrigation water depths decreased with SMP threshold decreased (Table 2). More numbers of irrigations were applied in 2013 and 2014 because the rainfall in both years was less than that in 2012. Compared to S1 treatment, the total amount of irrigation water for S2, S3, S4 and S5 decreased by $9 \%, 19 \%, 28 \%$ and $40 \%$ in $2012 ; 12 \%, 30 \%, 50 \%$ and $62 \%$ in 2013 and, $18 \%, 30 \%, 39 \%$ and $52 \%$ in 2014 , respectively.

\subsubsection{Soil matric potential}

Fig. 3 shows the change in SMP immediately under the emitters at $20 \mathrm{~cm}$ depth and for the different treatments in 2012, 2013 and 2014. It indicated that in most cases the SMP at $20 \mathrm{~cm}$ depth was basically affected by the target value of the SMP. The average SMP increased as the target value increased and the fluctuation in SMP value changed significantly as the target SMP decreased. During the second irrigation stage in 2012, all the treatments were uniformly irrigated and the SMP was basically maintained at higher than $-5 \mathrm{kPa}$. After this stage, each treatment reached the target SMP value.

Rainfall had an effect on the target SMP threshold. The lower SMP thresholds such as $-15,-20$ and $-25 \mathrm{kPa}$ treatments were

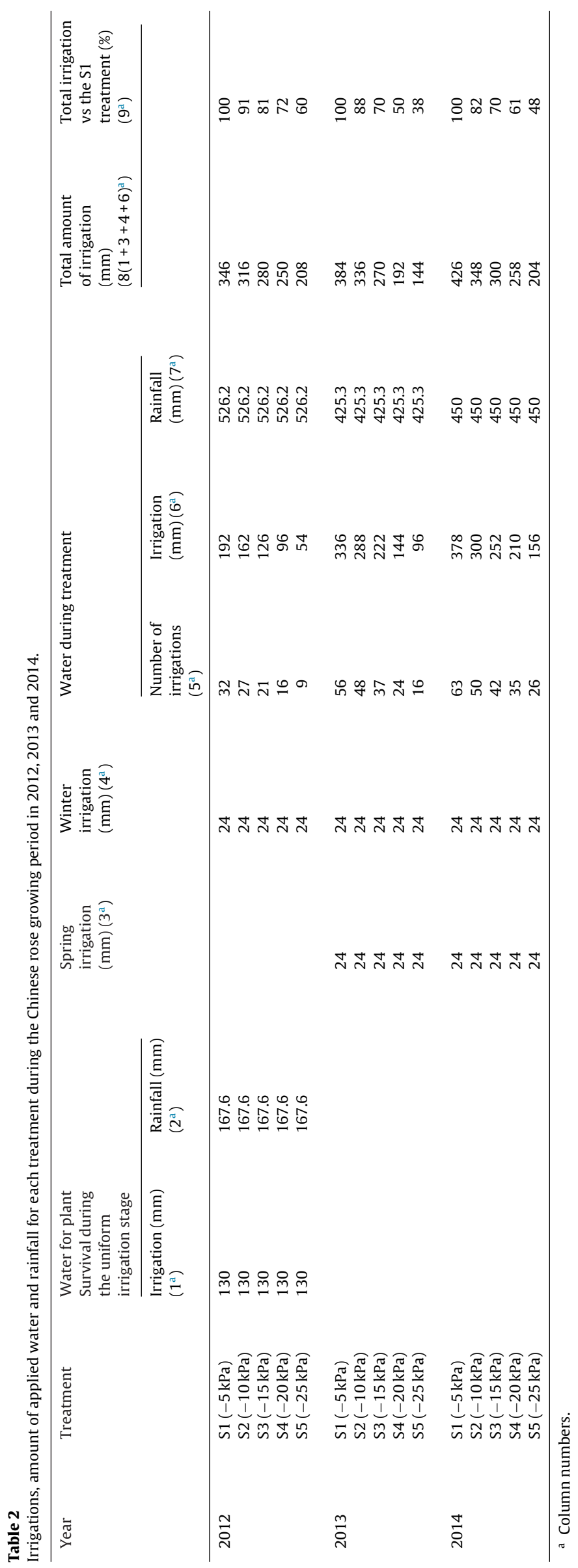



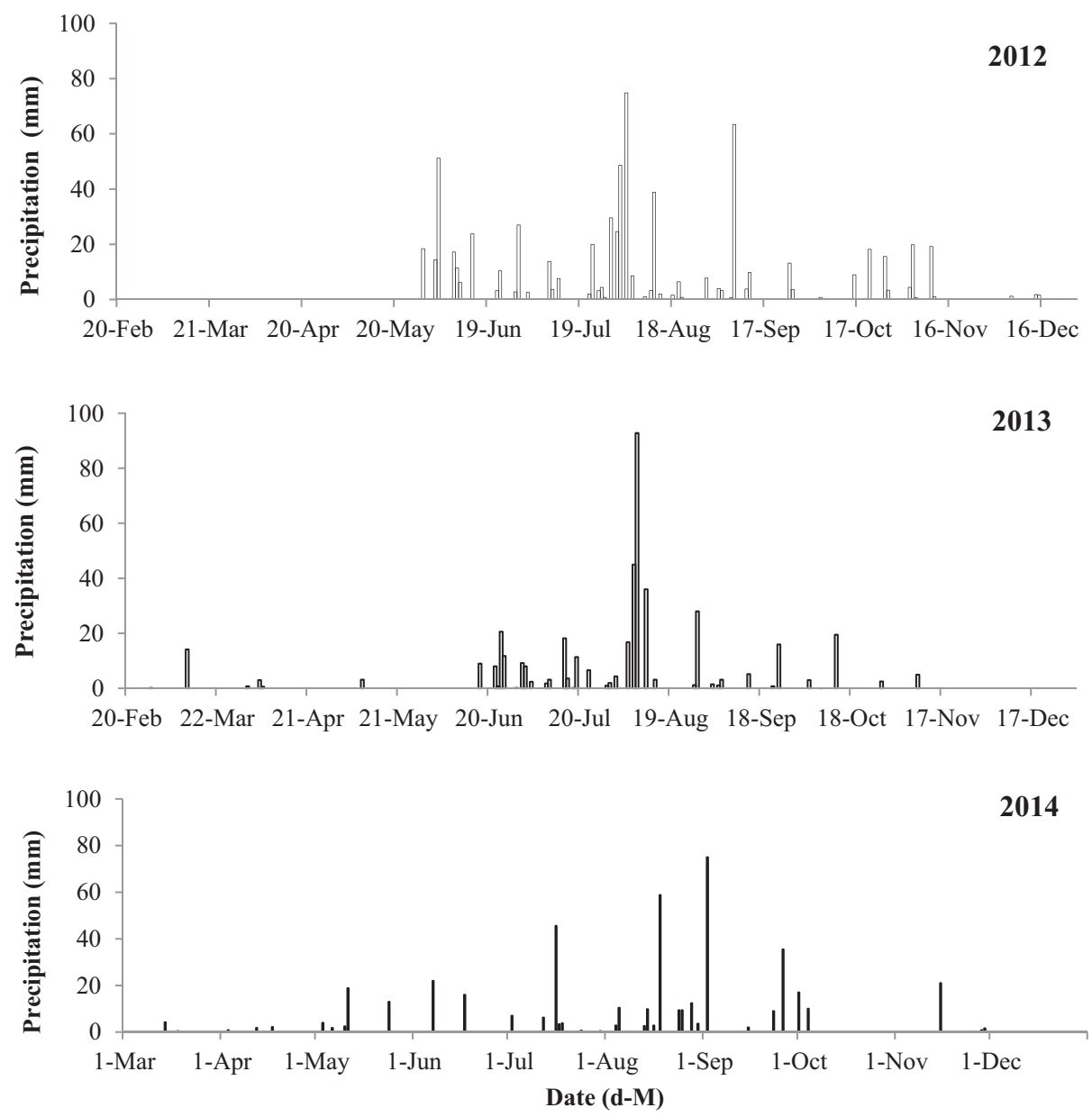

Fig. 2. Precipitation during treatment periods in 2012, 2013 and 2014.

more significantly affected by rainfall than the S1 treatment, especially during the rainy season, e.g. the continued rainfall events from 22 July to 12 August and 2 to 12 September in 2012; 1 to 14 August in 2013 and, 7 to 16 June and 25 September to 9 October in 2014.

\subsection{Soil salinity (ECe)}

\subsubsection{ECe spatial distribution}

The soil salinity spatial distributions for the SMP treatments are shown in Figs. 4 and 5. The ECe value before the roses had established was taken as the initial soil ECe value for each SMP treatment (Fig. 4A). The salt had mainly accumulated in the upper $0-30 \mathrm{~cm}$ soil layer where ECe was generally higher than $26 \mathrm{dS} \mathrm{m}^{-1}$ and the ECe of 0-10 $\mathrm{cm}$ layer was $34 \mathrm{dS} \mathrm{m}^{-1}$. The initial mean ECe values for the root zone $(0-40 \mathrm{~cm})$ and for the whole soil profile $(0-120 \mathrm{~cm})$ were $29.1 \mathrm{dS} \mathrm{m}^{-1}$ and $25.7 \mathrm{dS} \mathrm{m}^{-1}$, respectively.

Fig. $4 \mathrm{~B}$ shows the ECe distributions after the reclamation stage. The salinity of the soil had fallen considerably, and the salt had moved downwards out of the root zone. Compared to the initial mean soil ECe (Fig. 4A), the mean ECe root zone values for the S1 S3 and S5 treatments were $6.5,7.5$ and $6.7 \mathrm{dS} \mathrm{m}^{-1}$, respectively, and the desalinization ratios were 78,74 and $77 \%$, respectively. The mean ECe values for the whole soil profile were 15.8, 16.0 and $16.2 \mathrm{dS} \mathrm{m}^{-1}$ for the S1, S3 and S5 treatments, respectively, and the desalinization ratios were 39,38 and $37 \%$, respectively. The results indicated that the reclamation stage resulted in a large reduction in soil salinity.
Fig. 5 shows the spatial distribution of the soil ECe values during treatment and over time. The low salinity zone enlarged in size with time (Fig. 5A-D). At the end of 2012, the soil salinity in the root zone for the $S 1, S 3$ and $S 5$ treatments had further decreased to 4.4, 5.0 and $6.8 \mathrm{dS} \mathrm{m}^{-1}$, respectively (Fig. $5 \mathrm{~A}$ ); $2.3,4.2$ and $5.1 \mathrm{dS} \mathrm{m}^{-1}$, respectively at the beginning of 2013 (Fig. 5B); 2.6, 4.3 and $5.2 \mathrm{dS} \mathrm{m}^{-1}$, respectively at the end of 2013 (Fig. 5C) and, 3.2, 3.6 and $4.2 \mathrm{dS} \mathrm{m}^{-1}$ respectively, at the end of 2014 (Fig. 5D). After three growing seasons, the mean ECe values in the root zones of S1, S3, S5 treatments (Fig. 5D) had decreased by 89,88 and $86 \%$, respectively, compared to the initial mean soil ECe (Fig. 4A). When the SMP was controlled at -5 and $-15 \mathrm{kPa}$, the soil salinity was between 3.2 and $3.6 \mathrm{dS} \mathrm{m} \mathrm{m}^{-1}$, thus allowing the salt-sensitive plants to grow.

Compared to the initial salinity of whole soil profile (Fig. 4A), the mean ECe values for the S1, S3 and S5 treatments further decreased to $4.4,5.0$ and $6.8 \mathrm{dS} \mathrm{m}^{-1}$, respectively by the end of 2012 (Fig. 5A), 2.9, 4.1 and $4.8 \mathrm{dS} \mathrm{m}^{-1}$, respectively, by the end of 2013 (Fig. 5C) and, 3.2, 3.8 and $4.2 \mathrm{dS} \mathrm{m}^{-1}$, respectively, by the end of 2014 (Fig. 5D). After three growing seasons, the mean whole soil profile ECe values (Fig. 5D) had decreased by $89 \%, 87 \%$ and $86 \%$ for the S1, S3 and S5 treatments, respectively, compared to the initial mean soil ECe (Fig. 4A). The salinity in whole soil profile was obviously reduced for all treatments.

\subsubsection{Relationship between ECe and SMP and the factors of ECe} reduction

The relationship between the mean ECe and SMP threshold value is shown in Fig. 6. The mean root zone ECe (Fig. 6A) and whole soil profile ECe (Fig. 6B) had a linear relationship with SMP 

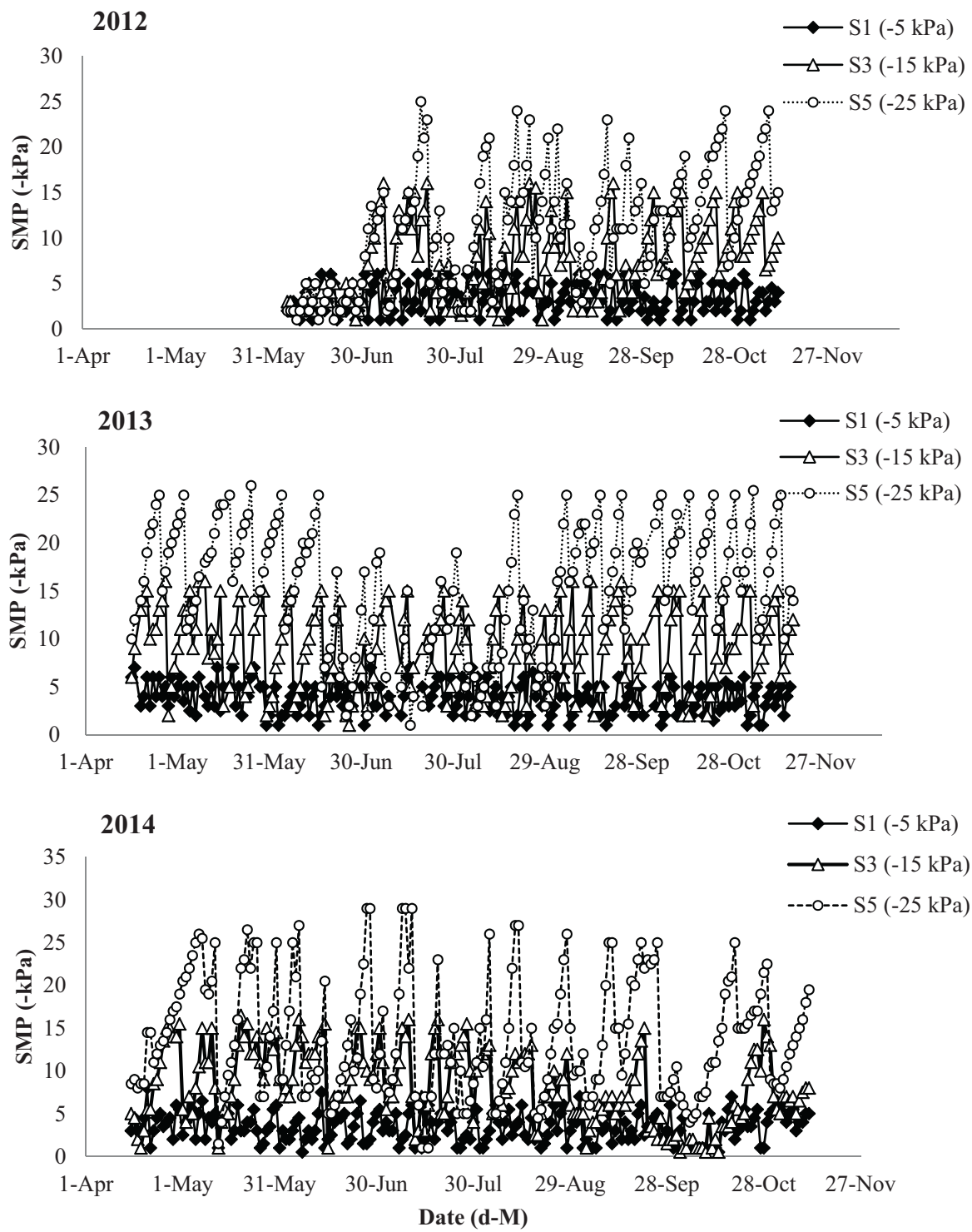

Fig. 3. The change of SMP (soil matric potential) at $20 \mathrm{~cm}$ depth immediately under emitters for different treatments in 2012,2013 and 2014.

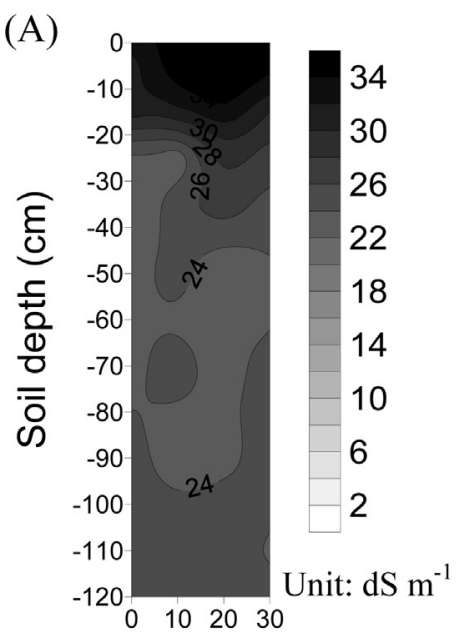

Distance from the emitter $(\mathrm{cm})$
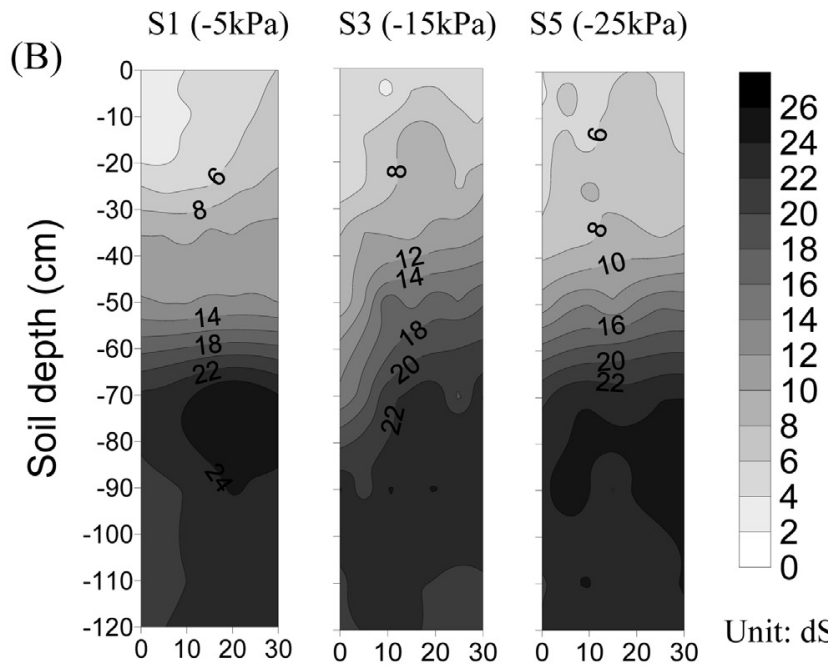

Unit: $\mathrm{dS} \mathrm{m}^{-1}$

Distance from the emitter $(\mathrm{cm})$

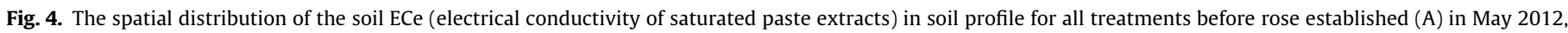
and for each treatment after the reclamation stage (B) in July 2012. 

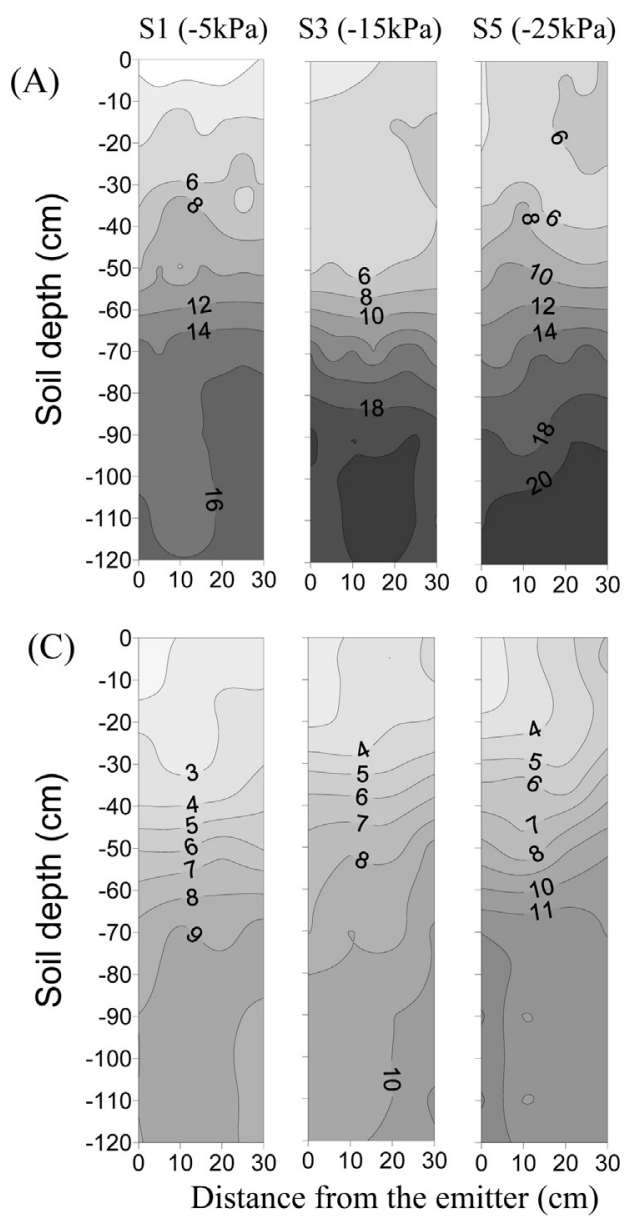

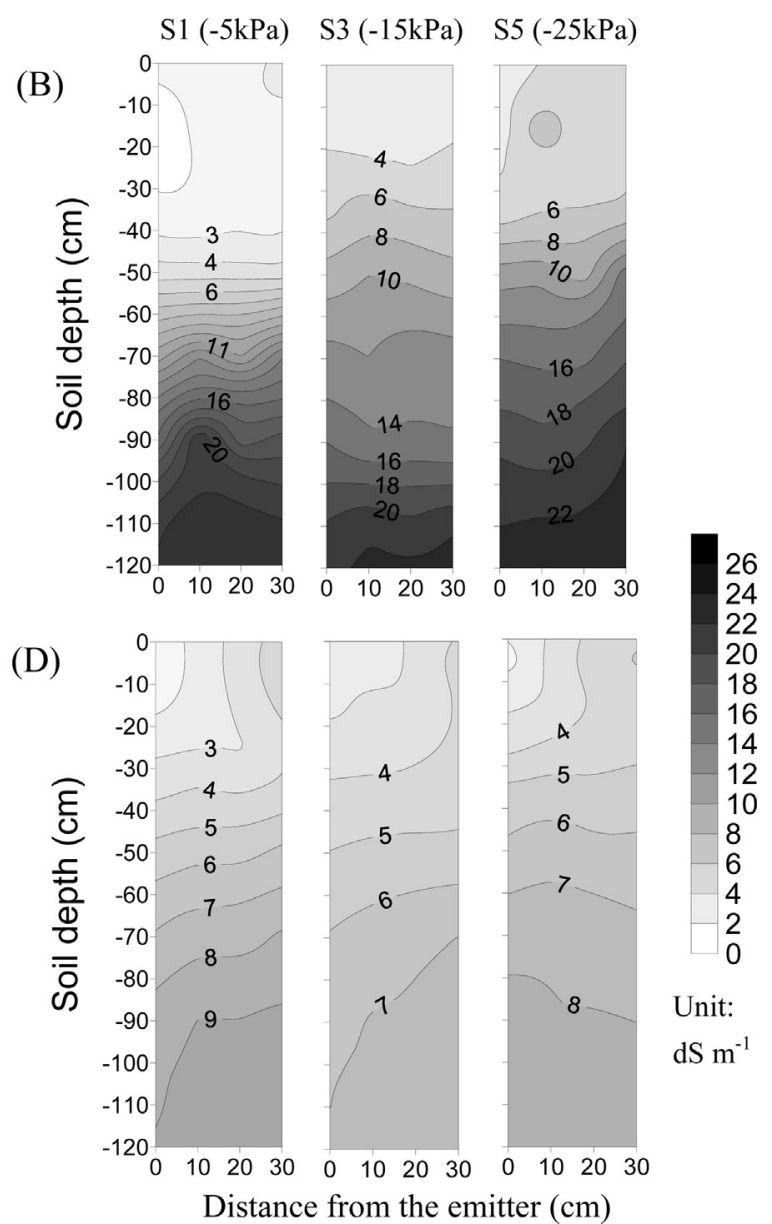

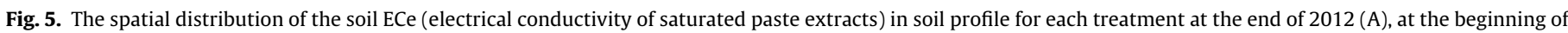
2013 (B), at the end of 2013 (C), and at the end of 2014 (D).

threshold and the ECe rose as the SMP threshold value decreased. The reason is that increasing the SMP threshold resulted in more irrigation water (Table 2). Compared to the mean whole soil profile ECe values on 30 October 2012 (Fig. 6B), the values for five SMP treatments did not decrease obviously on 24 May 2013, but the values in root zone on 24 May 2013 were obviously lower than the values on 30 October 2012 (Fig. 6A). It shows that the soil salinity in root zone was leached into the deeper layers $(40-120 \mathrm{~cm})$ by the winter irrigation on 25-30 November 2012.
The mean soil salinity values after reclamation stage (ECe) were different for all treatments due to soil spatial variability and it may have affected the treatment values, so the contribution of time, SMP, the ECe value and the interactions of time $\times$ SMP on the soil salinity during 2012 and 2013 were evaluated (Table 3). The analysis showed remarkably significant $(p \leq 0.01)$ differences for soil salinity in both the root zone and the whole soil profile with respect to time, SMP and ECe, but no significant $(p \leq 0.05)$ differences for time $\times$ SMP.

Table 3

Tests of between-subjects effects with factors of time, SMP (treatment), the ECe and SARe values before five SMP threshold treatments established in experiment zone, and interactions.

\begin{tabular}{|c|c|c|c|c|c|c|c|}
\hline Dependent variable & Soil depth $(\mathrm{cm})$ & Source & Type III sum of squares & df & Mean square & $F$ & Sig. \\
\hline \multirow[t]{5}{*}{ EC } & $0-40$ & Time & 31.034 & 3 & 10.345 & 15.517 & 0.000 \\
\hline & & $\mathrm{ECe}$ & 32.302 & 1 & 32.302 & 48.454 & 0.000 \\
\hline & & SMP & 183.379 & 4 & 45.845 & 7.382 & 0.000 \\
\hline & & ECe & 2874.233 & 1 & 2874.233 & 462.785 & 0.000 \\
\hline & & Time $\times$ SMP & 23.276 & 12 & 1.940 & 0.312 & 0.986 \\
\hline \multirow{7}{*}{ SAR } & & SMP & 151.599 & 4 & 37.900 & 11.706 & 0.000 \\
\hline & & SARe & 207.154 & 1 & 207.154 & 63.986 & 0.000 \\
\hline & & Time $\times$ SMP & 24.351 & 12 & 2.029 & 0.627 & 0.811 \\
\hline & $0-120$ & Time & 2468.890 & 3 & 822.963 & 99.788 & 0.000 \\
\hline & & SMP & 449.330 & 4 & 112.333 & 13.621 & 0.000 \\
\hline & & SARe & 8285.239 & 1 & 8285.239 & 1004.619 & 0.000 \\
\hline & & Time $\times$ SMP & 49.294 & 12 & 4.108 & 0.498 & 0.913 \\
\hline
\end{tabular}




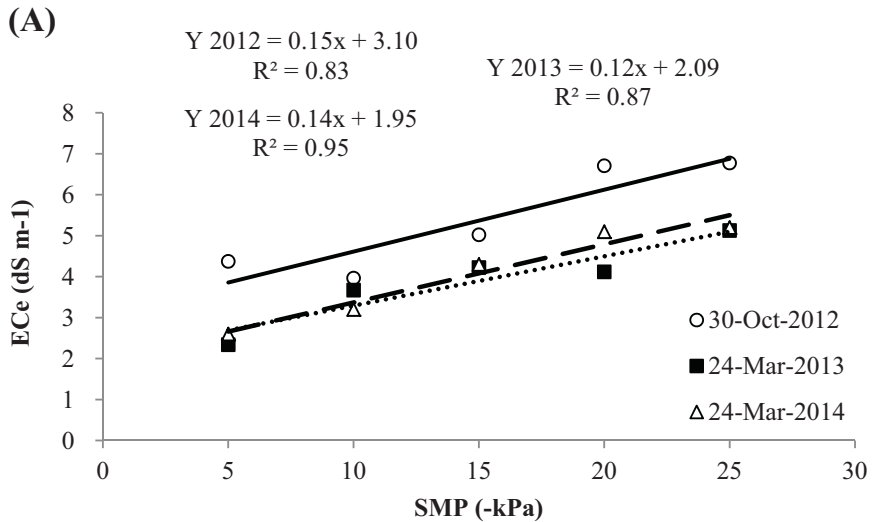

(B)

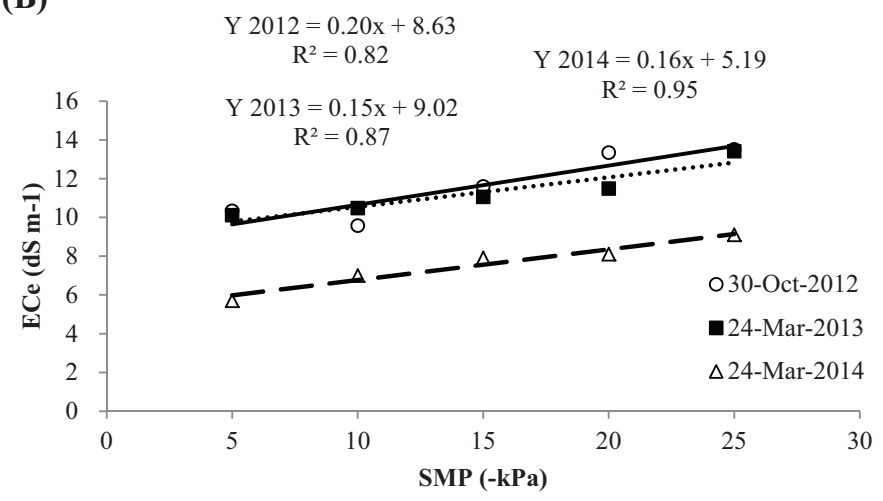

Fig. 6. Relationships between the mean ECe (electrical conductivity of saturated paste extracts) and SMP (soil matric potential) threshold value in root zone (A) and in whole soil profile (B).

In short, the mean soil salinity in the root zone and whole soil profile significantly reduced after three growing seasons and the $-5 \mathrm{kPa}$ treatment led to the largest ECe reduction. However, the soil salinity throughout the whole soil profile was still higher than the salt threshold of rose and could still potentially threaten plant growth.

\subsection{Sodium adsorption ratio (SAR)}

\subsubsection{The spatial distribution of the SAR}

Figs. 7 and 8 show the spatial distribution of the soil SAR for each SMP treatment. The spatial distribution of the SAR in the soil profile was closely related to the ECe levels and the soil zone with the lower ECe value corresponded to the lower SAR. Similarly the soil zone with the higher salt levels corresponded to the higher SAR value (Fig. 7B and Fig. 8A-C). Fig. 7A shows that the initial soil SAR was $61.0\left(\mathrm{mmol} \mathrm{L}^{-1}\right)^{0.5}$ for the root zone and $57.4\left(\mathrm{mmol} \mathrm{L}^{-1}\right)^{0.5}$ for the whole soil profile.

Fig. 7B shows the SAR distributions after the reclamation stage. The higher SAR values were located in the $60-120 \mathrm{~cm}$ soil layer and the zone with the lower SAR values were located in the upper soil layers. The mean SAR values for S1, S3 and S5 treatments decreased to $26.4,28.4$ and $27.8\left(\mathrm{mmol} \mathrm{L}^{-1}\right)^{0.5}$, respectively, and the reduction ratio was $56.8,53.4$ and $54.4 \%$, respectively, compared to the initial mean root zone SAR. The mean SAR values for the whole root profile decreased to 42.1, 42.2 and $43.2\left(\mathrm{mmol} \mathrm{L}^{-1}\right)^{0.5}$, respectively, and the reduction ratio was $26.7,26.4$ and $24.7 \%$, based on the initial mean SAR value in whole soil profile (Fig. 7A). The results indicated that the reclamation stage had a significant effect on the initial SAR reduction.

Fig. 8 shows the soil SAR distributions during each treatment. The mean soil SAR values in the root zone and the whole soil profile decreased year by year for all the SMP threshold treatments. The mean root zone SAR values for the S1, S3 and S5 treatments were $26.1,27.2$ and $28.8\left(\mathrm{mmol} \mathrm{L}^{-1}\right)^{0.5}$ by the end of 2012 (Fig. 8A); 18.8, 21.2 and $23.0\left(\mathrm{mmol} \mathrm{L}^{-1}\right)^{0.5}$ by the end of 2013 (Fig. $8 \mathrm{~B}$ ), and 16.3 , 18.6 and $20.2\left(\mathrm{mmol} \mathrm{L}^{-1}\right)^{0.5}$ by the end of 2014 (Fig. 8C), respectively. Besides, the mean whole soil profile SAR values for the S1, S3 and S5 treatments were 34.2, 37.4 and $38.6\left(\mathrm{mmol} \mathrm{L}^{-1}\right)^{0.5}$ by the end of 2012 (Fig. 8A); 26.6, 28.7 and $30.1\left(\mathrm{mmol} \mathrm{L}^{-1}\right)^{0.5}$ by the end of 2013 (Fig. 8B), and 23.4, 23.8 and $25.5\left(\mathrm{mmol} \mathrm{L}^{-1}\right)^{0.5}$ by the end of 2014 (Fig. 8C), respectively. After three growing seasons, the mean soil SAR values for S1, S3 and S5 treatments had decreased by $73.2 \%, 69.5 \%$ and $66.9 \%$ for the root zone and by $59.2 \%$, $59.9 \%$ and $55.6 \%$ for the whole soil profile, respectively, based on the initial SAR values (Fig. 7A). The SAR values in the root zone and the whole soil profile were obviously reduced for all treatments.

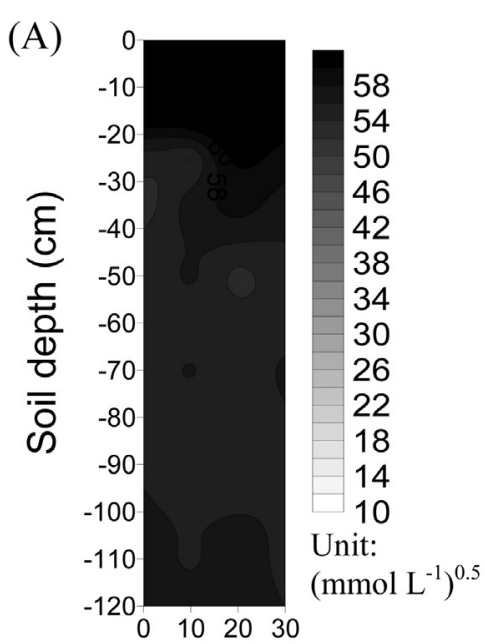

Distance from the emitter $(\mathrm{cm})$

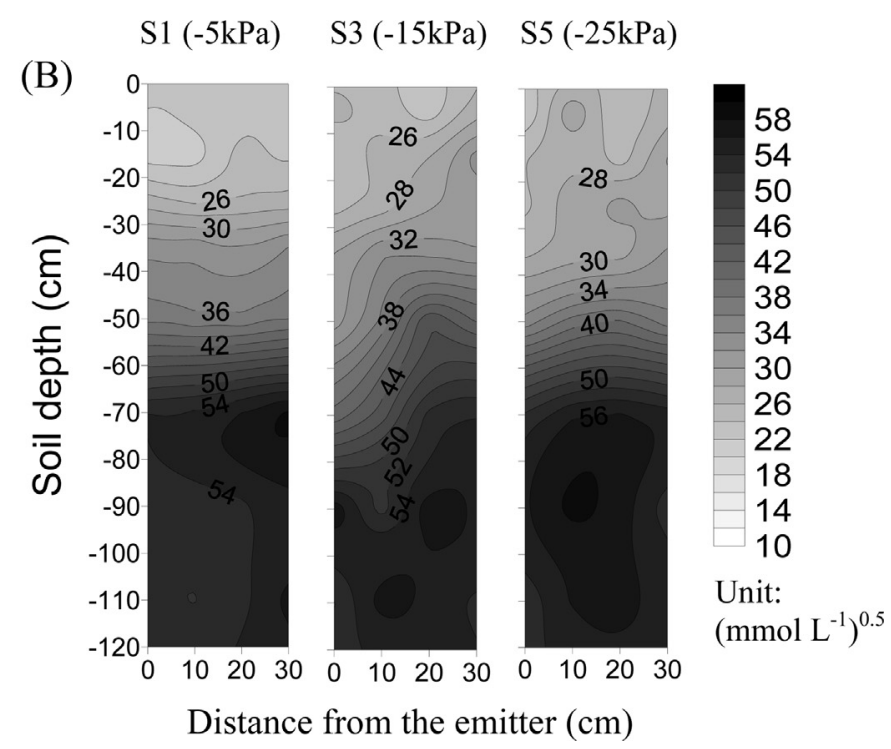

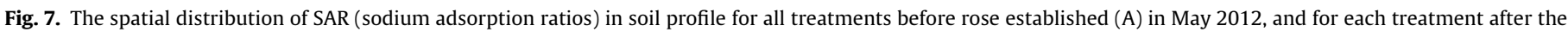
reclamation stage (B) in July 2012. 


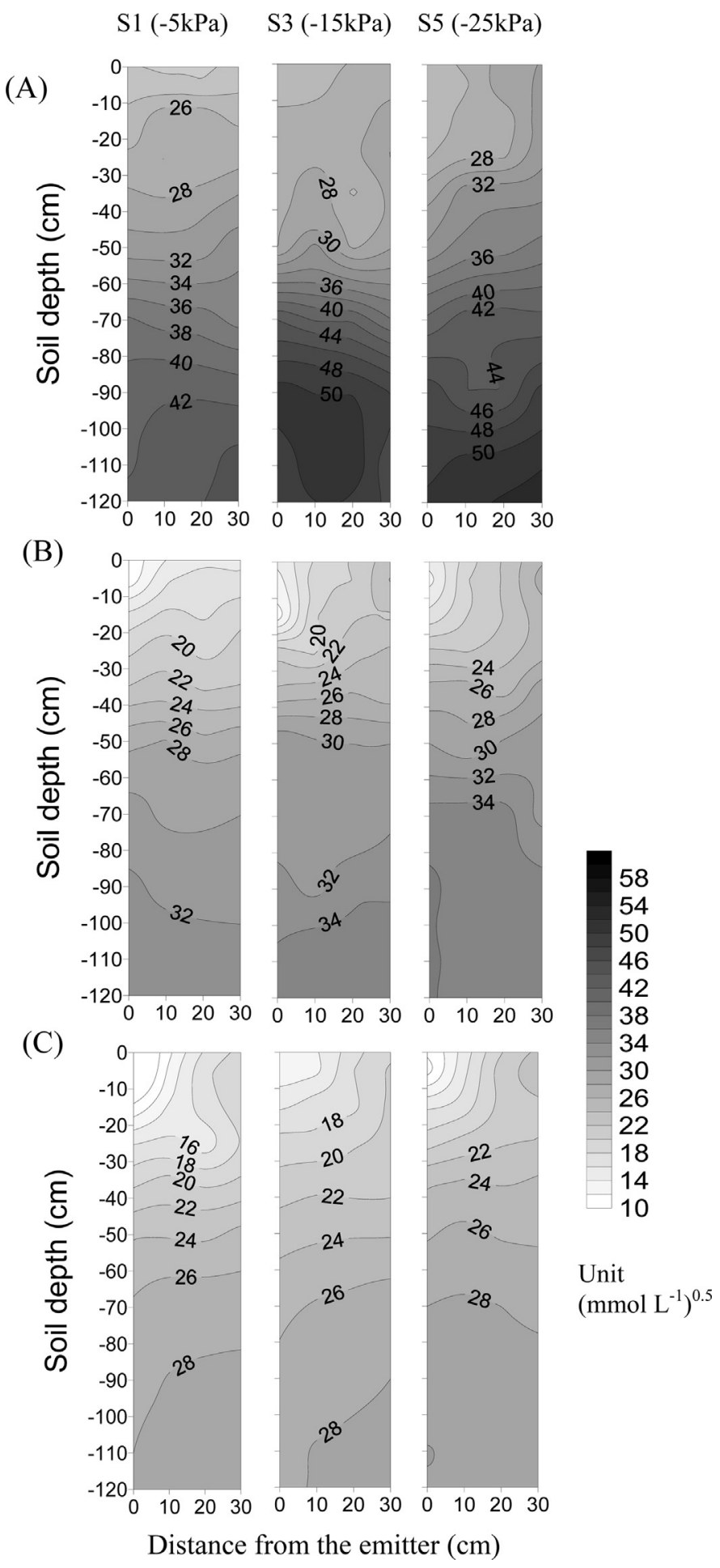

Fig. 8. The spatial distribution of SAR (sodium adsorption ratios) in soil profile for each treatment at the end of 2012 (A), at the end of 2013 (B), and at the end of 2014 (C).

\subsubsection{Relationship between SAR and SMP and the factors of SAR reduction}

The relationship between the mean SAR and SMP threshold values is shown in Fig. 9. The mean SAR value increased linearly with the SMP threshold decreased. After three growing seasons, the mean SAR values ranged from 16.3 to $20.2\left(\mathrm{mmol} \mathrm{L}^{-1}\right)^{0.5}$ for the root zone and ranged from 23.7 to $25.5\left(\mathrm{mmol} \mathrm{L}^{-1}\right)^{0.5}$ for the whole soil profile. The SAR values for all treatments were still higher than $13\left(\mathrm{mmol} \mathrm{L}^{-1}\right)^{0.5}$ (Holmes, 1982), which still had a potential sodium hazard on plant growth.

The mean soil SAR values after the reclamation stage (SARe) were different for all treatments and it may have affected the treatment values, so the contributions of time, SMP, the SARe value and the interactions of time $\times$ SMP on the SAR during 2012 and 2013 were evaluated (Table 3 ). The analysis showed remarkably significant $(p \leq 0.01)$ differences for SAR in both the root zone and the whole soil profile with respect to time, SMP and SARe, but no significant $(p \leq 0.05)$ differences for time $\times$ SMP.

After three growing seasons, the soil SAR values in the root zone and whole soil profile significantly reduced for all SMP threshold treatments and the $-5 \mathrm{kPa}$ treatment led to the greatest SAR reduction.

\subsection{Chinese rose growth characteristics}

\subsubsection{Growth characteristics}

Table 4 shows that the stem diameters and plant heights increased year by year and there was a significant difference $(p<0.05)$ between the SMP treatments. The stem diameters and plant heights of the $-5 \mathrm{kPa}$ threshold treatment in 2012 were greater than the other four SMP treatments, and both indexes had the largest values with control SMP of $-10 \mathrm{kPa}$ at the end of 2013 and $-20 \mathrm{kPa}$ at the end of 2014 . The average crown diameter of the $-25 \mathrm{kPa}$ threshold treatment at the end of 2013 and of the -10 and $-15 \mathrm{kPa}$ threshold treatments at the end of 2014 was significantly lower $(p<0.05)$ than the other SMP treatments and the largest crown was found when the SMP threshold was controlled at $-5 \mathrm{kPa}$ at the end of 2013 and at $-20 \mathrm{kPa}$ at the end of 2014, which showed the best ornamental crowns.

The data of survival ratio at the end of the growing seasons were used to analyze the significant level among all treatments. Table 5 shows that the survival ratio was not significantly different $(p<0.05)$ at the end of 2012, but was significantly different $(p<0.05)$ at the end of 2013, while it did not change afterwards. The difference of survival ratio among five treatments actually occurred in the spring of the second growing season. The reasons of the results above may be:

(1) Although the soil ECe values in root soil layer (Fig. 4B) were higher than rose's salt threshold values, no roses died during the reclamation stage; it indicates that the non-saline sandy soil provided a suitable environment for root regrowth during the stage. Later in 2012, enough water was provided by drip irrigation and by the high rainfall to ensure that the soil salt was continuously leached downward into gravel-sand layer and away from the root growth zone (Table 2). However, the whole soil profile salinity was still high which threatened the rose root environment as the roots grew larger, so a small number of roses died at the end of 2012.

(2) From 30 October 2012 to 25 April 2013, there was no rainfall and enough irrigation water for salt leaching. The dry air and wind allowed the salt in the lower soil depths to move up into the non-saline soil in the root zone, especially when the non-woven fabric covers were removed on 5 March 2013. When roses sprouted in the spring of 2013, the mean root zone ECe value for the $-5 \mathrm{kPa}$ treatment was below the salt threshold value, but the other SMP threshold treatments were above the salt threshold value (Fig. 5B). Therefore, the survival rate was significantly different in the spring of 2013 and this confirmed the effects of soil salinity on plant growth during the early stages of salt leaching.

(3) The salt in root zone at the end of 2013 and 2014 exceeded the salt threshold value for roses, but the rose survival rate at the 
(A)
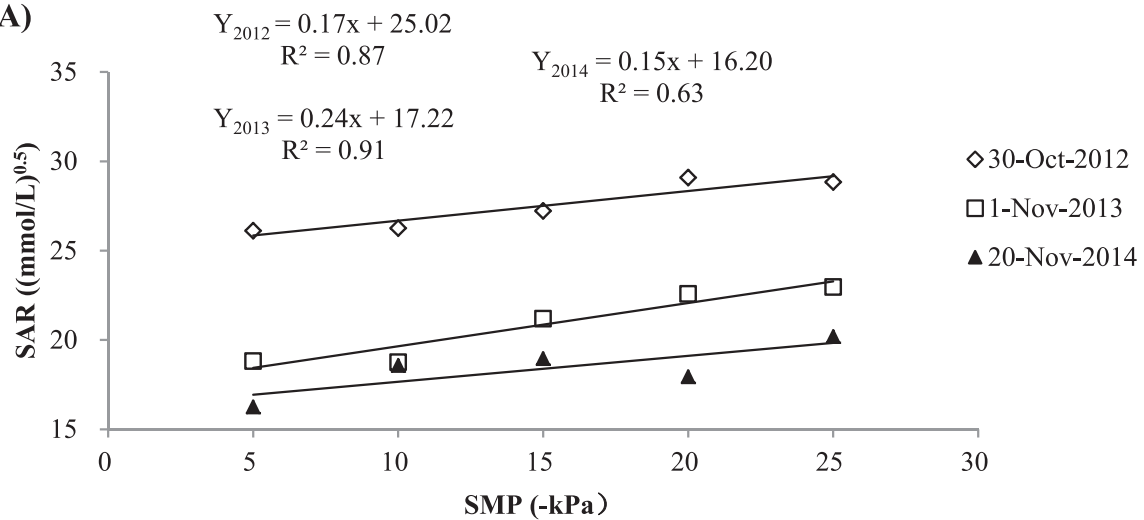

(B)

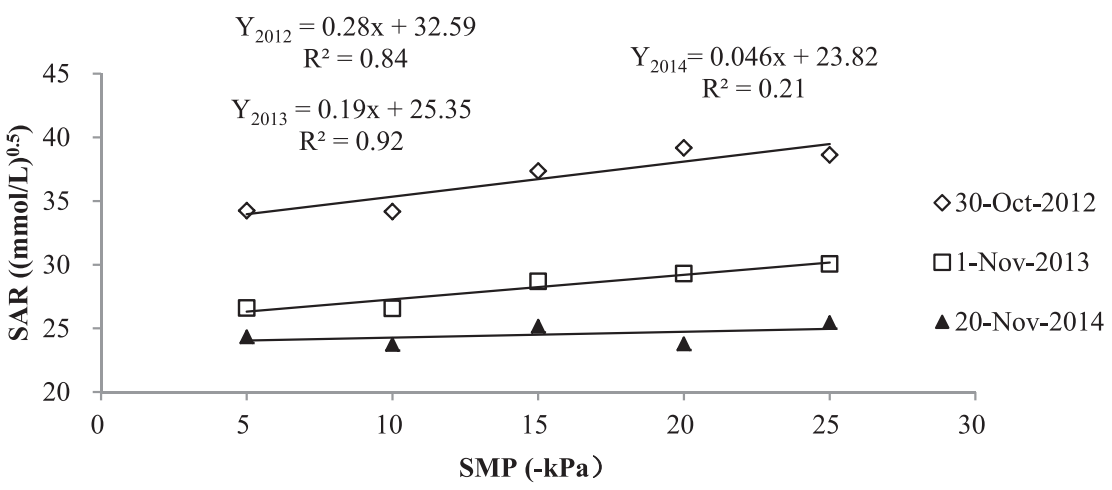

Fig. 9. Relationship between the mean SAR (sodium adsorption ratios) and SMP (soil matric potential) threshold value in root zone (A) and in whole soil profile (B).

Table 4

Growth indices of Chinese rose at the end growing seasons in 2012, 2013 and 2014

\begin{tabular}{|c|c|c|c|c|}
\hline Years & Treatments & Stem diameter (mm) & Plant height (cm) & Average crown diameter $(\mathrm{cm})$ \\
\hline \multirow[t]{5}{*}{2012} & $\mathrm{~S} 1(-5 \mathrm{kPa})$ & $8.1 \mathrm{a}$ & $70.6 a$ & \\
\hline & $\mathrm{S} 2(-10 \mathrm{kPa})$ & 7.2ab & $56.6 b$ & \\
\hline & $\mathrm{S} 3(-15 \mathrm{kPa})$ & 7.2ab & $58.3 b$ & \\
\hline & $\mathrm{S} 4(-20 \mathrm{kPa})$ & $6.7 b$ & $54.4 \mathrm{~b}$ & \\
\hline & $\mathrm{S} 5(-25 \mathrm{kPa})$ & $6.5 \mathrm{~b}$ & $49.0 \mathrm{~b}$ & \\
\hline \multirow[t]{5}{*}{2013} & $\mathrm{~S} 1(-5 \mathrm{kPa})$ & $12.6 a$ & $106.6 a$ & $49.7 \mathrm{a}$ \\
\hline & $\mathrm{S} 2(-10 \mathrm{kPa})$ & 13.3a & 109.1ab & $48.1 \mathrm{a}$ \\
\hline & $\mathrm{S} 3(-15 \mathrm{kPa})$ & $12.7 \mathrm{a}$ & 97.6abc & $45.2 \mathrm{a}$ \\
\hline & $\mathrm{S} 4(-20 \mathrm{kPa})$ & $12.4 \mathrm{a}$ & $97.2 \mathrm{bc}$ & $44.0 \mathrm{a}$ \\
\hline & $\mathrm{S} 5(-25 \mathrm{kPa})$ & $10.5 b$ & $78.7 c$ & $38.1 b$ \\
\hline \multirow[t]{5}{*}{2014} & $\mathrm{~S} 1(-5 \mathrm{kPa})$ & $13.0 \mathrm{a}$ & 119.6ab & $64.5 \mathrm{ab}$ \\
\hline & $\mathrm{S} 2(-10 \mathrm{kPa})$ & $12.7 \mathrm{a}$ & $99.1 \mathrm{c}$ & $58.5 b$ \\
\hline & $\mathrm{S} 3(-15 \mathrm{kPa})$ & $12.9 a$ & 109.3bc & $60.6 b$ \\
\hline & $\mathrm{S} 4(-20 \mathrm{kPa})$ & $13.8 \mathrm{a}$ & $130.2 \mathrm{a}$ & 71.1a \\
\hline & $\mathrm{S} 5(-25 \mathrm{kPa})$ & $13.8 \mathrm{a}$ & 119.6ab & $64.5 \mathrm{ab}$ \\
\hline
\end{tabular}

Values in the same column followed by the same letter are not significantly different at $p \leq 0.05$.

Table 5

Survival ratio of Chinese rose in growing seasons in 2012, 2013 and 2014.

\begin{tabular}{|c|c|c|c|c|c|}
\hline \multirow[t]{2}{*}{ Treatments } & \multicolumn{5}{|c|}{ Survival ratio (\%) } \\
\hline & $2012-7-1$ & 2012-10-30 & $2013-4-25$ & $2013-10-30$ & 2014-10-20 \\
\hline $\mathrm{S} 1(-5 \mathrm{kPa})$ & 100 & $99 a$ & 97 & $97 a$ & 97 \\
\hline $\mathrm{S} 2(-10 \mathrm{kPa})$ & 99 & $99 a$ & 89 & 89ab & 89 \\
\hline $\mathrm{S} 3(-15 \mathrm{kPa})$ & 99 & $98 \mathrm{a}$ & 83 & $83 b$ & 83 \\
\hline $\mathrm{S} 4(-20 \mathrm{kPa})$ & 100 & $99 a$ & 69 & $69 c$ & 69 \\
\hline $\mathrm{S} 5(-25 \mathrm{kPa})$ & 100 & $98 a$ & 60 & $60 c$ & 60 \\
\hline
\end{tabular}

Values in the same column followed by the same letter are not significantly different at $p \leq 0.05$. 


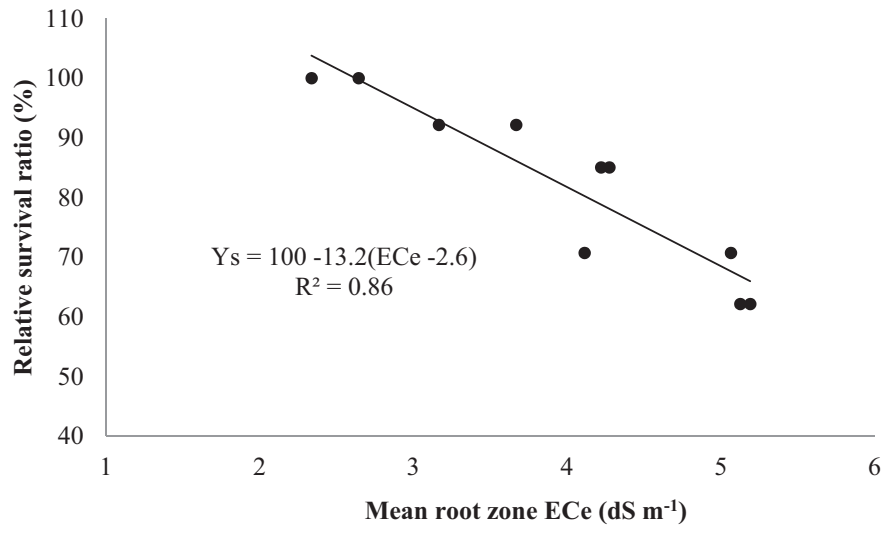

Fig. 10. Response of rose survival to mean ECe (electrical conductivity of saturated paste extracts) in the root zone.

end of 2013 and 2014 did not change. The main reason may be that the salinity in the whole soil profile decreased continuously in 2013 and 2014 (Fig. 5C-D). Another reason may be that the rose plants grew large to resist the salt stress, or they adapted to the salty environment in root zone after three growing years.

The survival ratio for the $-5 \mathrm{kPa}$ treatment was the highest at more than $97 \%$ for three growing seasons. It meant that there was limited salt stress. If irrigation was carried out in the first growing season with controlling the SMP at $-5 \mathrm{kPa}$, the risk of salt stress on survival ratio of rose could be significantly decreased in the spring of second year (Table 5); based on the above treatment, the SMP adjusted to $-10 \mathrm{kPa}$ in the second year and $-20 \mathrm{kPa}$ in the third year resulted in the largest values of plant height and stem diameter (Table 4). Moreover, compared to the $-5 \mathrm{kPa}$ treatment, less irrigation water was applied for the SMP treatment at $-10 \mathrm{kPa}$ in the second year and $-20 \mathrm{kPa}$ in the third year (Table 2). Considering larger plant growth and less irrigation water, this study suggested that the SMP at $-5 \mathrm{kPa}$ in the first year, $-10 \mathrm{kPa}$ in the second year and $-20 \mathrm{kPa}$ in third year should be used as the threshold to trigger drip irrigation when attempting to cultivate Chinese rose in the coastal saline soil.

\subsubsection{Relationship between survival ratio and root-zone soil salinity (ECe)}

The relative survival rate $\left(Y_{s}\right.$, which was the survival ratio of each treatment divided by that of S1 treatment in this study) responses to the mean root zone ECe values are shown in Fig. 10. According to Maas and Hoffman (1977), salt tolerance can be expressed by the following equation:

$Y_{S}=100-Y_{d} \times(\mathrm{ECe}-\mathrm{ECt})$

where $Y_{S}$ is the relative rose survival ratio. ECe represents the mean root zone salinity in the spring of 2013 and $2014\left(\mathrm{dS} \mathrm{m}^{-1}\right.$, in this study, the soil salinity in the spring affected the roses survival); ECt is the threshold salinity level that does not significantly reduce the plant survival ratio below that of a non-saline soil $\left(\mathrm{dS} \mathrm{m}^{-1}\right)$ and $Y_{d}$ is the survival rate decrease per unit of salinity increase beyond the threshold. tion:

Eq. (4) can be expressed in the form of the Maas-Hoffman equa-

$Y_{S}=100-13.2 \times(\mathrm{ECe}-2.6) R^{2}=0.86$

Eq. (5) revealed that $Y_{S}$ decreased by $13.2 \%$ for every $1 \mathrm{dS} \mathrm{m}^{-1}$ increase in the mean root zone ECe above $2.6 \mathrm{dS} \mathrm{m}^{-1}$, which is the salt threshold value for Chinese rose and was within the range provided by Maas and Hoffman (1977).

\subsection{The improved method for reclamation of coastal saline soil under drip irrigation}

According to the results of this study, the improved method was proposed as follows:

(1) Set a non-saline root environment (bigger than the root ball of the plant) to protect salt-sensitive plant growth at the early stage of salt-leaching;

(2) Set a gravel-sand layer beneath saline soil to prevent upward movement of the saline groundwater;

(3) Design the soil thickness above the gravel-sand layer of $1.2 \mathrm{~m}$ or larger to provide more moisture and nutrients for green plants growth, especially for shrubs and trees;

(4) Design the "reclamation stage" during the early stage of salt leaching. In this stage, to rapidly leach salinity of the upper soil layer and protect the non-saline root environment, the distance of close drip tubes was designed at $0.3 \mathrm{~m}$ and the emitter discharge rate was as low as $0.3 \mathrm{Lh}^{-1}$. When the ECe (measured with an in situ conductivity meter) at $0-20 \mathrm{~cm}$ was around $3 \mathrm{dS} \mathrm{m}^{-1}$, the distance of close drip tubes was adjusted to $0.6 \mathrm{~m}$ with controlling the SMP at $-5 \mathrm{kPa}$ to trigger irrigation; and

(5) In the normal irrigation stage, the SMP was controlled at $-5 \mathrm{kPa}$ in the first year, $-10 \mathrm{kPa}$ in the second year and $-20 \mathrm{kPa}$ in the third year so as to obtain a high survival ratio and good landscape effects.

Moreover, the experiment was only carried out for three years. It can be inferred that with the continuous leaching of salts, the saline soils will be reclaimed, and the SMP threshold could be controlled at lower value to make full use of the rainfall (the local mean annual precipitation is $607 \mathrm{~mm}$ ), save irrigation water and reduce the cost of management, Therefore, studies over a longer time scale are needed.

\section{Conclusions}

The field experiment was conducted over three growing seasons using the coastal saline soil surrounding Bohai Bay. The results showed the number of irrigations and the amount of irrigation decreased with decreased SMP threshold. Both the reclamation stage and SMP had significant effects on ECe and SAR. During the reclamation stage, the reduction ratios of soil salinity and SAR were higher than $74 \%$ and $53 \%$ in root zone, $36 \%$ and $22 \%$ in whole soil profile, respectively, based on initial soil salinity and SAR values. During the SMP treatment period, the mean ECe and SAR values linearly decreased with the increase of SMP. After three growing years, the highest rates of salt and SAR reduction in the root zone were recorded when the SMP was controlled at $-5 \mathrm{kPa}$, and the values were $89 \%$ and $73 \%$, respectively, compared with initial soil salinity and SAR values.

The five SMP threshold treatments had effects on the rose survival ratio, stem diameter, plant height and average crown diameter in the three years. The rose survival ratios for all the SMP treatments were higher than $97 \%$ in the first growing season. With the decrease of SMP, the survival ratios decreased in the spring of second year, and then remained stable in the following season. The highest survival ratio was $97 \%$ for the $-5 \mathrm{kPa}$ treatment after three years experiment. Both stem diameter and plant height increased year by year and the highest values were recorded in the $-5 \mathrm{kPa}$ treatment in the first year, $-10 \mathrm{kPa}$ treatment in the second year and $-20 \mathrm{kPa}$ treatment in the third year. The largest average crown diameter was obtained with controlling the SMP at $-5 \mathrm{kPa}$ in the second year and $-20 \mathrm{kPa}$ in the third year. 
Considering water saving, soil salt reduction, survival ratio and growth characteristics, the SMP value of $-5 \mathrm{kPa}$ in the first year, $-10 \mathrm{kPa}$ in second year and $-20 \mathrm{kPa}$ in third year was recommended as the threshold to trigger drip irrigation for Chinese rose cultivation in this coastal saline soil. Besides, the improved method of comprise a "reclamation stage" and a non-saline root environment during the early stages of salt leaching and a gravel-sand layer below the saline soil but above the water table should also be considered in the reclamation of costal saline soil.

\section{Acknowledgements}

This study was supported by the National High Technology R\&D Program of China (Grant Nos. 2013BAC02B02 and 2013BAC02B01), the Knowledge Innovation Program of the Chinese Academy of Sciences (Grant No. KZCX2-YW-359), and the Action Plan for the Development of Western China of the Chinese Academy of Sciences (Grant No. KZCX2-XB3-16).

\section{References}

Bao, S.D., 2000. Soil and Agricultural Chemistry Analysis. China Agricultural Press, Beijing, pp. 189-192 (in Chinese).

Cao, W.Z., Wong, M.H., 2007. Current status of coastal zone issues and management in China: a review. Environ. Int. 33, 985-992.

Hanson, B.R., 1995. Drip irrigation of row crops: an overview. In: Fifth International Microirrigation Congress-Microirrigation for a Changing World: Conserving Resources/Preserving the Environment, Orlando, pp. 651-655, vol. 95.

Hanson, B.R., May, D.M., 2003. Drip irrigation increases tomato yields in salt-affected soil of San Joaquin Valley. Calif. Agric. 57, 132-137.

Hanson, B.R., May, D.E., Simunek, J., Hopmans, J.W., Hutmacher, R.B., 2009. Drip irrigation provides the salinity control needed for profitable irrigation of tomatoes in the San Joaquin Valley. Calif. Agric. 63, 131-136.

He, M., Sakurai, K., Wang, G.Q., Chen, Z.H., Shu, Y., Xu, J.J., 2003. Physico-chemical characteristics of the soils developed from alluvial deposits on Chongming Island in Shanghai, China. Soil Sci. Plant Nutr. 49, 223-229.

Hoogerwerf, M.R., Muchena, F.N., Stein, A., 1992. Spatial variability and reclamation of salinity and sodicity in a Kenyan Irrigation Scheme. Soil Technol. 5, $121-134$.

Holmes, J.C., 1982. Modern irrigated soils-James, DW, Hanks, RJ, Jurinak, JJ. Crop Res. 22, 125-126.

Jiao, Y.P., Kang, Y.H., Wan, S.Q., Sun, Z.J., Liu, W., Dong, F., 2008. Effect of soil matric potential on the distribution of soil salt under drip irrigation on saline and alkaline land in arid regions. Trans. CSAE 6, 53-58 (in Chinese with English abstract).

Kang, Y.H., Wan, S.Q., 2005. Effect of soil water potential on radish (Raphanus sativus L.) growth and water use under drip irrigation. Sci. Hortic.-Amsterdam 106, 275-292.

Kang, Y.H., Wan, S.Q., Jiao, Y.P., Tan, J.L., Sun, Z.Q., 2008. Saline soil salinity and water management with tensiometer under drip irrigation. In: Symposia on the fifth
Annual Meeting of Agricultural Land and Water Engineering of Chinese Society of Agricultural Engineering, Shihezi City, China, pp. 124-131 (in Chinese).

Liu, S.H., Kang, Y.H., Wan, S.Q., Wang, Z.C., Liang, Z.W., Sun, X.J., 2011. Water and salt regulation and its effects on Leymus chinensis growth under drip irrigation in saline-sodic soils of the Songnen Plain. Agric. Water Manage. 98, 1469-1476.

Maas, E.V., Hoffman, G.J., 1977. Crop salt tolerance-current assessment. J. Irrig. Drain. Div. 2, 115-134.

Maas, E.V., 1986. Salt tolerance of plants. Appl. Agric. Res. 1, 12-26.

Manjunatha, M.V., Oosterbaan, R.J., Gupta, S.K., Rajkumar, H., Jansen, H., 2004. Performance of subsurface drains for reclaiming waterlogged saline lands under rolling topography in Tungabhadra irrigation project in India. Agric. Water Manage. 69, 69-82.

Musslewhite, B.D., Vinson, J.R., Johnston, C.R., Brown, T.H., Wendt, G.W., Vance, G.F., 2009. Salinity and sodicity of weathered minesoils in northwestern New Mexico and northeastern Arizona. J. Environ. Qual. 38, 1266-1273.

Phene, C.J., Davis, K.R., Hutmacher, R.B., Baryosef, B., Meek, D.W., Misaki, J., 1991. Effect of high-frequency surface and subsurface drip irrigation on root distribution of sweet corn. Irrig. Sci. 12, 135-140.

Ravindran, K.C., Venkatesan, K., Balakrishnan, V., Chellappan, K.P., Balasubramanian, T., 2007. Restoration of saline land by halophytes for Indian soils. Soil Biol. Biochem. 39, 2661-2664.

Ritzema, H., Schultz, B., 2011. Optimizing subsurface drainage practices in irrigated agriculture in the semi-arid and arid regions: experiences from Egypt, India and Pakistan. Irrig. Drain. 60, 360-369.

Schuman, G.E., Depuit, E.J., Roadifer, K.M., 1994. Plant-responses to gypsum amendment of sodic bentonite mine spoil. J. Range Manage. 47, 206-209.

Sun, J.X., Kang, Y.H., Wan, S.Q., Hu, W., Jiang, S.F., Zhang, T.B., 2012. Soil salinity management with drip irrigation and its effects on soil hydraulic properties in north China coastal saline soils. Agric. Water Manage. 115, 10-19.

Sun, J.X., Kang, Y.H., Wan, S.Q., 2013. Effects of an imbedded gravel-sand layer on reclamation of coastal saline soils under drip irrigation and on plant growth Agric. Water Manage. 123, 12-19.

Tan, J.L., Kang, Y.H., 2009. Changes in soil properties under the influences of cropping and drip irrigation during the reclamation of severe salt-affected soils. Agric. Sci. China 8, 1228-1237.

Wan, S.Q., Jiao, Y.P., Kang, Y.H., Jiang, S.F., Tan, J.L., Liu, W., Meng, J., 2013. Growth and yield of oleic sunflower (Helianthus annuus L.) under drip irrigation in very strongly saline soils. Irrig. Sci. 31, 943-957.

Wang, R.S., Kang, Y.H., Wan, S.Q., Hu, W., Liu, S.P., Liu, S.H., 2011. Salt distribution and the growth of cotton under different drip irrigation regimes in a saline area. Agric. Water Manage. 100, 58-69.

Wang, Z.Q., Zhu, S.Q., Yu, R.P., et al., 1993. Salt-affected Soils of China. Science Press, Beijing, pp. 145-146 (in Chinese).

Yu, Y.P., Chen, D.M., 1999. The development and utilization of saline soil resources in China. Chin. J. Soil Sci. 4, 158-159 (in Chinese).

Yue, Y.J., Zhang, F., Zhang, G.M., Zhang, H., Xu, P.H., Wang, J.A., 2010. Coastal salinealkali land use change and its optimization: a case study on the 'raised fieldshallowpond' pattern in Huanghua County. Resour. Sci. 3, 423-430 (in Chinese with English abstract).

Zedler, J.B., Morzaria-Luna, H., Ward, K., 2003. The challenge of restoring vegetation on tidal, hypersaline substrates. Plant Soil 253, 259-273.

Zhang, T.B., Kang, Y.H., Wan, S.Q., 2013. Shallow sand-filled niches beneath drip emitters made reclamation of an impermeable saline-sodic soil possible while cropping with Lycium barbarum L. Agric. Water Manage. 119, 54-64. 